\title{
Humor en prediking
}

\begin{tabular}{|c|c|}
\hline \multicolumn{2}{|c|}{$\begin{array}{l}\text { Authors: } \\
\text { Gerbrand Bodenstein }{ }^{1} \text { (D) } \\
\text { Cas Wepener }{ }^{1} \text { (D) }\end{array}$} \\
\hline \multicolumn{2}{|c|}{$\begin{array}{l}\text { Affiliations: } \\
{ }^{1} \text { Department of Practical } \\
\text { Theology, Faculty of Theology } \\
\text { and Religion, University of } \\
\text { Pretoria, South Africa }\end{array}$} \\
\hline \multicolumn{2}{|c|}{$\begin{array}{l}\text { Research Project Registration: } \\
\text { Project Leader: C.J. Wepener } \\
\text { Project Number: } 04461012\end{array}$} \\
\hline \multicolumn{2}{|c|}{$\begin{array}{l}\text { Description: } \\
\text { Gerbrand Bodenstein is } \\
\text { participating in the research } \\
\text { project 'Homiletics and } \\
\text { Liturgy', directed by } \\
\text { Prof. Dr Cas Wepener, } \\
\text { Department of Practical } \\
\text { Theology, Faculty of Theology } \\
\text { and Religion, University of } \\
\text { Pretoria, South Africa. }\end{array}$} \\
\hline \multicolumn{2}{|c|}{$\begin{array}{l}\text { Corresponding author: } \\
\text { Gerbrand Bodenstein, } \\
\text { gerrie.bodenstein@gmail.com }\end{array}$} \\
\hline \multicolumn{2}{|c|}{$\begin{array}{l}\text { Dates: } \\
\text { Received: } 01 \text { Dec. } 2017 \\
\text { Accepted: } 20 \text { July } 2018 \\
\text { Published: } 22 \text { Nov. } 2018\end{array}$} \\
\hline \multicolumn{2}{|c|}{$\begin{array}{l}\text { How to cite this article: } \\
\text { Bodenstein, G. \& } \\
\text { Wepener, C., 2018, 'Humor } \\
\text { en prediking', HTS Teologiese } \\
\text { Studies/Theological Studies } \\
\text { 74(2), a4890. https://doi. } \\
\text { org/10.4102/hts.v74i2.4890 }\end{array}$} \\
\hline \multicolumn{2}{|c|}{$\begin{array}{l}\text { Copyright: } \\
\text { (C) 2018. The Authors } \\
\text { Licensee: AOSIS. This } \\
\text { is licensed under the } \\
\text { Creative Commons } \\
\text { Attribution License. }\end{array}$} \\
\hline \multicolumn{2}{|l|}{ Read online: } \\
\hline 口ifor & $\begin{array}{l}\text { Scan this QR } \\
\text { code with your } \\
\text { smart phone or } \\
\text { mobile device } \\
\text { to read online. }\end{array}$ \\
\hline
\end{tabular}

Humor is an integral part of society. The idea that humor and laughter are good for one's health and psyche is well known, and many researchers praise the role that humor plays in society. Humor also plays an important role in Christian preaching and is found in various sermon contexts. However, whether the humor used in preaching is always of good quality, is doubtful. This article aims to highlight the role of humor in preaching. The phenomenon of humor and the role of humor in the Bible is described and, lastly, the use of humor in preaching is explored.

\section{Inleiding ${ }^{1}$}

Die wonderlike voordele wat humor vir die menslike samelewing, psige en liggaam inhou, is alombekend (Lefcourt \& Martin 2012; Martin 2004; Miller \& Fry 2009; Spitzer 2006). Mediese, sosiale en antropologiese navorsers het in die verlede al talle kere deur verskeie studies bewys dat humor en lag 'n positiewe uitwerking op die menslike liggaam en psige het, en ook kan bydra tot spoedige genesing van siektes en kwale (Arminen \& Halonen 2007; Lebowitz et al. 2011; Martin 2007:310-330).

Die goot rol wat humor in die samelewing speel, het ook oorgespoel na die praktyk van die prediking en liturgie - van 'n rugby-grappie aan die begin van 'n Gereformeerde erediens, tot 'n uurlange 'stand-up' komedie vertoning in 'n charismatiese erediens. Humor word uiteraard gebruik oor 'n breë spektrum van eredienste, op 'n verskeidenheid maniere.

Dit wil egter voorkom of humor in prediking tot op hede min aandag ontvang het in homiletiese werke. Duidelik is daar geen tekort aan goeie homiletiek handboeke ${ }^{2}$ nie. As daar egter in meer diepte na homiletiek handboeke gekyk word, word dit duidelik dat handboeke min, en somtyds niks, te sê het oor die gebruik van humor in prediking nie. Navorsing wat bestaan, berus hoofsaaklik op aanhalings, staaltjies en outeurs se menings. Die paar teoloë en homilete ${ }^{3}$ wat oor hierdie onderwerp skryf, sien humor egter as ' $n$ toepaslike instrument om in prediking gebruik te word. Daar is baie duidelik 'n diskrepansie tussen die praktyk van prediking en die akademiese veld van die homiletiek as dit by humorgebruik kom.

Die vraag waarop hierdie artikel lig wil werp, is: Is die sinvolle/effektiewe gebruik van humor in die prediking moontlik? Ten einde hierdie vraag te verken, sal daar eerstens gekyk word na wat humor is; daarná sal gekyk word of humor in die Bybel teenwoordig is; en laastens sal daar uitgebrei word op humor se rol in prediking.

\section{Wat is humor?}

Humor is 'n raaiselagtige verskynsel wat moeilik is om te definieer (Theron 1996:212). Daar is ' $n$ magdom verskillende definisies van humor - elkeen gebaseer op ander uitgangspunte. Uit die oorvloed van definisies ${ }^{4}$ is Goldman (2009:84) se definisie deegliker as ander, aangesien dit fokus

1.Hierdie artikel is gebaseer op die nagraadse navorsing van die eerste outeur, en die tweede outeur was die studieleier.

2.Thomas Long se werk, The witness of preaching (2016), Tisdale en Troeger, A Sermon Workbook: Exercises in the Art and Craft of Preaching (2013), Johan Cilliers se werk, Die lewende stem van die evangelie (2004), Henk van der Meulen se Nederlandse preekhandleiding, Als een leerling leren preken (2008), tot by die werk van Fred B. Craddock, Paul Scott Wilson, David Buttrick, John McLure en Eugene Lowry, om maar enkeles hier uit te sonder.

3.Onder andere Campbell en Cilliers (2012), Cilliers (2008, 2009, 2010), Drakeford (1986), Hyers (1987), Theron (1996), Webb (1998) en Whedbee (1998).

4.Die Oxford definisie word verder uitgebrei: 'The faculty of perceiving what is ludicrous or amusing, or of expressing it in speech, writing, or other composition; jocose imagination or treatment of a subject' (Simpson en Weiner 1989). Finestad definieer humor as: 'The quality that makes something laughable or amusing' (Finestad 2010:14). Die Handwoordeboek van die Afrikaanse Taal (HAT) beskryf humor as 'die lagwekkende; geestigheid; komieklikheid; skerts. Die voorstelling van omstandighede of uiting van gedagtes gekenmerk humor as 'die lagwekkende; geestigheid; komieklikheid; skerts. Die voorstelling van omstandighede of
deur verrassende teenstellings, speelse wendings en ongerymdhede' (Gouws, Luther \& Pheiffer 2015).

Note: This article represents reworked aspects of the MTh-thesis of Gebrand Bodenstein, titled, 'Humor en prediking in ' $n$ veranderende Suid-Afrikaanse konteks', completed under the supervision of Prof. Dr Cas Wepener, Department of Practical Theology, University of Pretoria. This article is published in the section Practical Theology of the Society for Practical Theology in South Africa. 
op die vermoë van 'n individu om te besef wat komies is. Goldman (2009:84) verwys na humor as: 'The ability to perceive, enjoy, or express what is amusing, comical, incongruous, or absurd'.

Humor is nie net 'n verskynsel wat lei tot 'n spesifieke tipe gedrag soos lag of glimlag nie-dit is ook 'n gemoedstoestand wat die amusanthede van die lewe waarneem. Humor produseer lag, wat genot en vreugde ontlok, sodat humor oor die algemeen beskou word as 'n positiewe vorm van kommunikasie wat samewerking en goedkeuring kan genereer (Finestad 2010:14). Dit is egter nie net vermaaklik nie, en ook nie noodwendig die teenoorgestelde van erns nie. Humor is 'n perspektief, 'n houding en 'n leefstyl wat mense help om effektiewer te kommunikeer en dus optimaal te leef. Humor kan mense ook in staat stel om nuwe moontlikhede raak te sien.

\section{Teorieë oor humor}

Daar is 'n verskeidenheid teorieë oor humor wat poog om te verduidelik waarom mense humor gebruik en waarom iets snaaks is. Die meeste skrywers is dit eens dat nie een teorie voldoende is om die veelsydige fenomeen van humor te verduidelik nie (Haig 1988:26). Daar is sommige akademici wat aandui dat daar meer as 100 voorgestelde teorieë van humor bestaan (Hart 2007:181).

Vandag word drie gewilde kategorieë van teorieë grotendeels aanvaar in akademiese kringe.

\section{Meerderwaardigheidsteorie (Humor as antisosiaal)}

Die meerderwaardigheidsteorie beweer dat lag of humor na vore kom as 'n uitdrukking van iemand se gevoelens van meerderwaardigheid teenoor ander (Morreall 2009:6). Iemand kan gesien word as komieklik wanneer hy of sy beskou word as: 'Inadequate according to a set of agreed-upon group or societal criteria' (Lynch 2011:426). Lag vir die onkundige optrede van ander, soos volwassenes dikwels lag vir die woorde of dade van kinders, illustreer hierdie perspektief (Meyer 2000:314).

\section{Teenstrydigheidsteorie (Humor as irrasioneel)}

Vanuit die perspektief van die teenstrydigheidsteorie, lag mense vir wat hulle verras en dit wat onverwags of vreemd is op 'n nie-dreigende manier (Meyer 2000:317). Teenstrydige verrassings trek 'n mens se aandag op 'n kognitiewe wyse en produseer'n emosionele gevoel van vreugde (Young 2009:19). Die groot rugbyspeler met die fyn stemmetjie illustreer hierdie perspektief.

\section{Verligtingsteorie (Humor as 'n uitlaatklep)}

Vanuit hierdie perspektief, lag mense en vind iets humoristies omdat hulle stresverligting ervaar op 'n sekere wyse (Meyer 2000:312). Die fisiologiese manifestasies of 'simptome' van humor is baie belangrik in hierdie siening, wat behels dat humor spruit uit die verligting wat ervaar word wanneer spanning verlig en verwyder word uit iemand se lewe. Humor is dan die gevolg van 'n vrystelling van senuweeagtige energie. Mense wat bedreig voel deur begrotingsbesnoeiings in hul organisasie, lag byvoorbeeld met verligting as vertel word dat die sjef nie meer klagtes gaan aanvaar oor die kos by die organisasie nie.

\section{Soorte humor}

Die humor waarmee ons te doen kry in ons alledaagse sosiale interaksie kan verdeel word in drie breë kategorieë (Martin 2007:10-15).

\section{Grappe}

Gedurende die loop van gesprekke vermaak mense dikwels ander deur grappe te vertel. Martin (2007:11) wys daarop dat 'n grap'n kort vermaaklike storie is wat eindig met' $n$ klimaks ('punch line'). Long en Graesser (1988:37) definieer 'n grap weer as enigiets wat gedoen of gesê word om doelbewus vermaaklik te wees.

In alledaagse gesprekke word grappe gewoonlik voorafgegaan deur verbale en/of nie-verbale leidrade (bv. 'Het jy al die een gehoor van ...'), of die grap voldoen aan 'n sekere formaat wat bekend is in sosiale kringe (bv. "n Dominee, 'n Jood en Jan van der Merwe sit in 'n kroeg ...'), wat 'n aanduiding aan die gehoor is dat die storie bedoel is om humoristies te wees en dat daar van die hoorders verwag word om te lag ná die vertelling, hoewel die grapvertellers nie altyd daarin slaag om hoorders te laat lag nie (Long 1989:14-20; Martin 2007:11).

Long en Graesser (1988:37) wys daarop dat grappe meestal nie konteksgebonde is nie. Alhoewel grapjasse dikwels die rigting waarin die gesprek verloop in ag neem wanneer ' $n$ grap vertel word, is grappe meestal nie konteksgebonde nie.

\section{Spontane humor}

Grappe is 'n belangrike, maar klein persentasie van die humor wat ervaar word in daaglikse interpersoonlike kommunikasie. Onlangse studies het getoon dat slegs $11 \%$ van lag in reaksie op grappe is. Hierdie $11 \%$ kan vergelyk word met $72 \%$ van lag wat afgelei is van spontane gesprekshumor wat, in teenstelling met grappe, baie afhanklik is van konteks (Martin 2007:12).

Spontane humor is meer konteksgebonde as grappe, en is dus dikwels nie agterna weer so snaaks nie. Menigmaal word die woorde 'jy moes daar gewees het' gebruik in situasies waar 'die oomblik verby is' om iets humoristies te vind. Die moontlikhede vir spontane humor is baie groter as voorbereide grappe - 'n mens kan net soveel grappe onthou, waar 'n skerpsinnige, spontane persoon heeltyd nuwe materiaal kan skep.

\section{Toevallige of onbedoelde humor}

Behalwe vir spontane humor en grappe, kan humor ook toevallig of onbedoeld wees. Alleen en Don Nilsen verwys na 
hierdie as 'toevallige humor', wat hulle verdeel in fisiese en taalkundige vorm (Martin 2007:14). 'n Groot deel van die humor wat in informele sosiale interaksie ontstaan, is dikwels die gevolg van gebeure wat nie opsetlik bedoel is om snaaks te wees nie. Iemand kan onbedoeld iets per ongeluk sê of doen wat humor ontlok, soos 'n persoon wat gly op 'n piesangskil of verwarrings wat deur sprekers veroorsaak word (Wyer \& Collins 1992:686).

\section{Negatiewe humor}

Alhoewel humor geprys word vir die wonderlike invloed wat dit op die menslike liggaam en psige het, is daar ook 'n negatiewe kant aan humor verbonde. John Morreall (2009) wys op drie nadelige effekte van humor. ${ }^{5}$

\section{Onverantwoordelikheid}

Humor kan mense losmaak van wat hulle doen of hul laat versuim om dit te doen. Baie sosiale probleme of kritiek word afgelag in plaas van om op gepaste wyse op te tree teenoor die probleme en kritiek. As 'n dokter aanbeveel dat iemand 'n streng dieet volg vir gesondheidsredes en die persoon lag die dokter af deur te sê: 'Die dokter is dan vetter as ek' en kies om die dokter se raad in die wind te slaan, is dit 'n goeie voorbeeld van onverantwoordelike humor.

Wanneer mense probleme aflag, word dit hanteer as onbelangrik en vra dus nie vir oplettendheid en aandag nie. Hierdie distansie of ontkoppeling, bevorder deur humor, word dikwels doelbewus gebruik deur politici om kritiek te deflekteer. Dit is baie duidelik in die Suid-Afrikaanse konteks waar voormalige president Jacob Zuma dikwels sy teenstanders wat hom gekritiseer het, afgelag ${ }^{6}$ het tydens parlementsittings (Martin 2007:119).

\section{Gebrek aan medelye}

Nog 'n manier waarop die onbetrokkenheid in humor skade kan veroorsaak, is deur die gebrek aan medelye vir diegene wat hulp nodig het. In sulke gevalle kan humor op twee maniere benadeel: deur die verplasing van aksie, en deur die belediging van lydende partye, wat hul lyding inderwaarheid vergroot (Morreall 2009:103). Veronderstel iemand stap langs die pad en sien 'n ander persoon wat gly, in 'n plas water val en sy rug beseer. As die persoon wat hom gesien val het, begin lag en hom nie help nie, sien die eerste persoon sy ongeluk as blote vermaak wat die persoon verkleineer en 'n gevoel van onverskilligheid by die toekyker skep. In gevalle van ligte lyding, word sulke humor as onsensitief of gevoelloos beskou, maar in ernstiger gevalle word dit wreedheid genoem.

\section{Bevordering van vooroordeel}

'n Derde skadelike effek van humor is gegrond in die manier waarop mense hulself kognitief distansieer van die voorwerp

5.Deur die geskiedenis heen is die oorgrote meerderheid morele evaluerings van humor negatief gevind. In Morreall se boek, Comic Relief (2009:92-98), beskryf hy agt tradisionele morele besware teen die gebruik van humor.

6.Martin (2007:119) wys daarop dat hierdie tipe lag 'decommitment' genoem word. van vermaak (Morreall 2009:105). Dit is in hierdie afdeling van die negatiewe etiek van humor waar rassistiese en seksistiese grappe na vore kom. Philips (1984:67) het reeds in 1984 die vraag: 'Is truth a defense against the charge of racism?' op hierdie verwoord as: 'What if members of that group really have or statistically tend to have an unflattering characteristic a joke attributes to them? Surely we are allowed to notice this and to communicate this information to one another?' Kundiges wys daarop dat die negatiewe in seksistiese en rassistiese grappe, die seksistiese en rassistiese oortuigings is wat hulle impliseer, op tipiese oortuigings oor ongewenste eienskappe in die teikengroep dui (Ford et al. 2008:159).

Soos grappe in die algemeen, is seksistiese en rassistiese grappe dikwels by beide vertellers en toehoorders bekend as fiktiewe verhale. Wat hierdie grappe gewoonlik skadelik maak, is dat hulle karakters met oordrewe grade van ongewenste eienskappe veronderstel wat groepe verteenwoordig wat sommige ander mense glo eintlik die eienskappe besit, byvoorbeeld dat 'n sekere groep lui is (Ford et al. 2008:160). ${ }^{7}$

\section{Humor in die Bybel}

Vir baie Christene beskryf woorde soos 'eerbiedig', 'kragtig', 'heilig' en 'geïnspireer' hulle begrip van die Bybel. Die woorde 'snaaks', 'lag', 'geestig' en 'humoristies' kan vir sommige wat die verhale en verkondigings van die Skrif ken, na effens verregaande beskrywings klink. Omdat humor 'n ietwat 'speelse' ingesteldheid en 'n gewilligheid om nie te ernstig te wees nie vereis, kan baie Christene huiwerig wees om te erken dat gedeeltes van die Skrif snaaks kan wees of dalk geskryf is deur mense wat met opset humor gebruik het (Herion 1992:325).

\section{Herion (1992) stel tereg:}

The assumption often is that religion is serious and that it demands a transformation of human nature - especially the eradication of that aspect of human nature that derives pleasure from 'worldly' things. Yet in the past century this theological assumption has been abandoned by many people, some of whom point out that humor can be a powerful vehicle for making important points, while others go further and insist that even biblical writing may have been intended primarily to entertain the reader. (p. 325)

Die vraag of daar humor in die Bybel is, is ' $n$ vraag waaroor al wyd in Christelike kringe gedebatteer is oor die eeue heen. Baie Bybellesers sal sekerlik saamstem met Baudelaire en Whitehead (in Whedbee 1998:1) se verklaring ${ }^{8}$ oor humor in die Bybel. Saam met baie filosowe, teoloë en literêre kritici beweer hulle dat die Bybel nie 'n aangename tuiste vir humor of die komiese is nie (Whedbee 1998:1). Tog verdedig die oorgrote meerderheid teoloë en Bybelkundiges die bestaan

7.In reaksie op die probleem van rassistiese humor, voer Hijri (2009) aan dat rasgebaseerde komedie ' $n$ platform kan bied om die kwessie van rassisme aan te pak; en die individue wat na vore tree as verteenwoordigers van rasgebaseerde pak; en die individue wat na vore tree as verteenwoordigers van
komedie, is verhoogkomediante soos Trevor Noah en Russel Peters.

8.Whitehead (in Whedbee 1998:1) stel: 'The total absence of humour in the Bible is one of the most singular things in all literatures'. 
van humor in die Bybel. Rogness (2012:123) stel tereg: 'Is there humor in the Bible? The more appropriate question would be how could there not be humor in the Bible?'

Van Heerden (2001:75-87) en Whedbee (1998:1-11) wys daarop dat daar verskeie faktore is wat 'n mens se siening van humor in die Bybel kan beïnvloed. Hierdie faktore is ook heel moontlik die rede waarom lidmate humor in prediking miskyk. Hierdie faktore sluit in: leesstrategieë, kulturele faktore, filosofiese tradisies, sosiale ligging, en verskeie ander.

\section{Humor in die Ou Testament}

Watter argumente ook al ter tafel gelê word om te bewys dat humor in die $\mathrm{Ou}$ Testament te vinde is, is een Bybelkundige se opmerkings oor hierdie kwessie van besondere belang. Greenstein (1992:330-331) erken dat die Bybel geen Hebreeuse term vir humor as sodanig het nie, en tog verdedig hy die idee dat humor deel is van die Bybelse tekste. Volgens Greenstein (1992:330) beweer geleerdes dat humor in verskillende literêre vorms of style verskyn. Hy stel ook verder: 'Humor is notoriously difficult to classify, and definitions of types vary ... biblical humor and wit often intermix a variety of types'.

\section{Verskeie invalshoeke van humor in die Ou Testament}

'n Groot aantal Bybelkundiges en geleerdes gebruik verskeie invalshoeke om humor in die Ou Testament te identifiseer en te verduidelik.

Karl-Josef Kuschel (1994; cf. Patella 2015) beskryf vier maniere waardeur lag en gelag in die Bybel, en spesifiek in die Ou Testament, voorkom as 'n manier om humor raak te sien: (1) Mense lag vir God, (2) God lag vir heersers, (3) God lag vir die goddeloses, en (4) die onpeilbare gelag van God (Kuschel 1994).

J. William Whedbee (1998:6-7) het 'n ander benadering gevolg. Hy het ' $n$ anatomie van humor en komedie in die Bybel geskets volgens vier interverwante perspektiewe: (1) intrige; (2) karakterisering van basiese tipes; (3) taalkundige en stilistiese strategieë; en (4) funksies en voornemens.

Verskeie navorsers fokus ook op die taalkundige verskynsels van humor in die Ou Testament. Hierdie invalshoek op humor in die Ou Testament is verweef met verskeie ander invalshoeke omrede 'n groot hoeveelheid humor in die Ou Testament van taalkundige en stilistiese strategieë, soos ironie, sarkasme, woordspeling en verskeie ander, gebruik maak.

\section{Enkele voorbeelde van Ou Testamentiese humor}

Toe koning Dawid met Batseba geslaap het en haar swanger gemaak het, was sy nog steeds met Urija getroud. In 'n poging om sy sonde te verdoesel, het koning Dawid 'n brief aan sy generaal, Joab, gestuur om vir Urija aan die voorste punt van die geveg te plaas sodat hy doodgemaak sou word. Die ironie is dat Dawid hierdie brief gestuur het saam met Urija, wat onbewustelik sy eie doodsbevel aan Joab oorgedra het (Finestad 2010:23).

Die profeet Samuel het koning Saul gevra waarom hy die skape van die Amalekiete gespaar het nadat hulle deur die Here gesê is om alles uit te roei. Samuel vra toe: 'Wat vir 'n geblêr van kleinvee is daar dan in my ore?' (1 Sam 15:14). Die woord vir 'dan' is meh (תחמוּ) wat onaangenaam klink soos die geblêr van skape. Dit is dus woordspeling en onomatopee. ${ }^{9}$

\section{Humor in die Nuwe Testament}

Die humor van Jesus geniet bo alle ander figure en boeke buite die evangelies die meeste aandag in die Nuwe Testament. 'n Algemene bewering, iets wat groot teologiese gewig dra, is die effek wat 'n sin vir humor op die begrip van Jesus as volkome mens sal hê (Martin 2011:57). Conrad Hyers (1987:16) vra: 'What does the full humanity of Jesus mean if it does not include the freedom of laughter and humour?'

Die eerste hoofstuk van die Johannes-evanglie vertel 'n verhaal van Natanael en Jesus wat dien as 'n bewys dat Jesus die vermoë gehad het om die humor van ander te herken en te waardeer.

\section{Enkele voorbeelde van die humor van Jesus}

Ironie is 'n algemene vorm van humor wat Jesus gebruik het. Ironie hang af van 'n kontras tussen voorkoms en werklikheid (Palmer 2001:71). Jesus het byvoorbeeld ironie gebruik toe hy Johannes die Doper verdedig het (Luk 7:24-25):

Waarna het julle in die woestyn gaan kyk? Na 'n riet wat deur die wind heen en weer gewaai word? Nee? Maar wat het julle dan uitgegaan om te sien? 'n Man met deftige klere aan? Nee, kyk, dié wat swierige klere dra en in weelde lewe, kry 'n mens in koninklike paleise.

Nog 'n vorm van humor wat Jesus gebruik het, was oordrywing of hiperbool. Jesus het gereageer op die vraag oor hoe moeilik dit is vir 'n ryk man om die koninkryk van God binne te gaan, met 'n oordrewe antwoord in Matteus 19:24: 'Dit is makliker vir 'n kameel om deur die oog van 'n naald te kom as vir 'n ryke om in die koninkryk van God te kom'. ${ }^{10}$

\section{Voorbeelde van ander Nuwe Testamentiese humor}

Alhoewel die grootste hoeveelheid humor in die Nuwe Testament aan Jesus toegeskryf word, is daar ook verskeie ander humoristiese verhale in die Bybel.

\footnotetext{
9.Debora se lied in Rigters 5, 1 Sameul 5 se verhaal van die Filistyne, en boeke soo Job, Jona en Ester bevat ook talle ander voorbeelde van Ou Testamentiese humor.

10.Campbell en Cilliers (2012:109) wys ook daarop dat Jesus dikwels in sy kontak met die owerhede die retoriese idees van 'n nar gebruik het. Jesus het ook van dwaasheid gebruik gemaak, byvoorbeeld in Matteus 5 (Campbell \& Cilliers 2012:113)
} 
Handelinge 12 wys waar Lukas Petrus se ontsnapping uit Herodes se gevangenis weergee (Patella 2015:160). Nadat hy van sy kettings en sel deur 'n engel bevry is, het Petrus na die huis van Markus se ma gegaan om sy medegelowiges die goeie nuus van sy ontsnapping te gaan vertel. Toe Petrus aan die voordeur klop, kom 'n diensmeisie met die naam Rode om die deur oop te maak. Toe sy Petrus se stem hoor, was sy verheug en het gehardloop om die ander te vertel dat Petrus vry was, maar sy het vergeet om die deur oop te maak! Petrus moes aanhou klop totdat die ander gekom het om die deur vir hom oop te maak. ${ }^{11}$

\section{Gevolgtrekking}

Dit is duidelik dat die meeste humor in die Bybel voorkom in 'n spesifieke konteks en nie sonder konteks verstaan kan word nie. Die meerderheid van gevalle van humor in die Bybel speel ook af in werklike omstandighede in spesifieke kontekste en is nie fiktief nie. Dit is hierdie idee wat van groot belang is vir prediking. Effektiewe gebruik van humor in prediking berus op meer as op die idee om 'n grappie tydens die erediens te vertel. Die Bybel maak dit duidelik dat ware humor weerspieël word in werklike omstandighede deur die aksies van gewone mense. Daar is selde situasies in die Bybel waar 'n eksplisiete grap vertel word. Paulus, Jesus of Moses sê byvoorbeeld nooit vir die volk of vir diegene wat hul geleer het: 'Laat ek gou vir julle 'n grappie vertel' nie. Humor word slegs gevind in ware lewenservarings, wat Bybelse humor in 'n mate meer natuurlik as geforseerd laat voorkom, en dien dus as 'n riglyn vir Christelike prediking.

\section{Humor in prediking}

Alhoewel die meeste teoloë en homilete ten gunste van humor se gebruik in prediking is, is daar verskeie teoloë wat beswaar maak teen die gebruik daarvan. Hierdie besware het vier redelik goed gedefinieerde vorme aangeneem oor die laaste paar jaar.

\section{Bybelse besware}

Hierdie besware spruit hoofsaaklik uit die beskouing wat lank gehuldig is oor die heiligheid van die Bybel, waar die Bybel gesien is as die heilige Woord van God en daarom kan niks oor die Bybel of die proklamasie daarvan snaaks wees nie (Finestad 2010:25).

\section{Teologiese besware}

Waarskynlik die mees geleeste en invloedrykste stelling oor humor was dié van Reinhold Niebuhr wat in 1946 sy boek, Discerning the Signs of the Times, die lig laat sien het. In dié boek het Niebuhr ' $n$ duidelike verband tussen die Christelike geloof en humor beskryf: 'Intimate relation between humor and faith is derived from the fact that both deal with the incongruities of our existence' (Capps 2016:ad loc). Hy tref 'n onderskeid tussen onmiddellike teenstrydighede waarby humor betrokke is en die uiteindelike teenstrydighede waarby geloof betrokke is.

11.Ander humoristiese verhale sluit in Handelinge 20:9-10 en Lukas 11:5-7.
Niebuhr (1946:111) stel: 'Laughter is our reaction to the immediate incongruities and those which do not affect us essentially', en: 'Faith is the only possible response to the ultimate incongruities of existence which threaten the very meaning of our life'.

Uiteindelik kom Niebuhr (1946) se argument daarop neer dat mense lag, en kan lag, oor die algemene ongeregtighede en teenstrydighede van die lewe, maar 'n mens kan nie lag oor die uiteindelike of fundamentele aspekte soos geloof en aanbidding, sonde en vergifnis nie.

\section{Etiese besware}

Die etiese besware teen humor in prediking sluit aan by Morreall (2009) se drie nadelige effekte van humor. Buiten Morreall is dit weereens Niebuhr wat groot uitspraak gelewer het teen die etiese gebruik van humor, spesifiek oor humor se onvermoë om die bose te hanteer. Niebuhr voer aan dat humor nie 'n gepaste reaksie op menslike boosheid is nie, onder andere die boosheid van onderdrukking, oorlog en hongersnood (Niebuhr 1946:111). Daar is natuurlik die gelag van die onderdrukker. Daar is ook die ewe skrikwekkende lag van diegene wat lag om hul meerderwaardigheid teenoor die onderdruktes te toon. Maar daar is ook die lag van die onderdruktes en dié wat werk om hulle te bevry. Dit is die gelag wat in die mees onmenslike omstandighede steeds menslikheid verseker (Campbell \& Cilliers 2012:154-155). Hierdie gelag beliggaam die nar as die prediker se primêre identiteit. Die identiteit wat die magte ontwrig en wat menslike swakheid beliggaam.

\section{Praktiese besware}

Praktiese besware wys op die verkeerde of negatiewe gebruik van humor in prediking. Dit sluit in die gebruik van grappe, sarkasme, aggresiewe humor en verskeie ander.

Humor op sigself is nie negatief nie, maar daar is egter sekere tipes humor wat negatief is en eerder nie gebruik moet word in prediking nie. In prediking is dit nooit aanvaarbaar om humor te inisieer net om die gemeente te laat lag nie. Dit is ook nooit aanvaarbaar om humor te gebruik ter wille daarvan om die aanvaarding van die gemeente te wen nie, of met die hoop dat die gemeente meer van 'n prediker sal hou as hy humoristies optree as wat hul andersins sou nie. Buttrick (1987:146) benadruk juis hierdie idee.

\section{Onaanvaarbare humor}

Dit moet vanselfsprekend aanvaar word dat daar humor is wat gepas is en humor wat onvanpas is tydens prediking. Nelson (1998:7) wys dat daar ongelukkig nie maklike en vinnige reëls is om te bepaal wat gepas is en wat nie. Daar kan egter uitgewys word watter humor om eerder te gebruik en wat om eerder te vermy. Dit is op die ou end elke prediker se eie verantwoordelikheid en keuse om goeie kanselhumor te gebruik.

Daar is verskeie onaanvaarbare humorsoorte wat eerder vermy moet word - 'n paar word kortliks uitgelig. 


\section{Grappe}

Een van die mees beklemtoonde tipes humor wat dikwels nie gesien word as goeie kanselgebruik nie, is om grappe te vertel tydens prediking. Talle teoloë en homilete (Buttrick 1987:95; Craddock 2010:219; Webb 1998) benadruk hierdie belangrike punt. Dikwels wanneer homilete en teoloë standpunt inneem teenoor humor tydens prediking, is dit in werklikheid die gebruik van grappe in preke wat hul teenstaan. Daar is teenstand teen grappe vanuit verskillende oogpunte. ${ }^{12}$ Craddock (2010) stel:

And humor will be humor; not jokes, at best a risky business and at worst a violation of the sermon. Humor, properly joined to the matter of the sermon, feels at home and is thus free to frolic, laugh, and celebrate the grace of God. (pp. 219-222)

Craddock (2010) sê verder:

Humor is, then, a genuine response to grace; grace works in us that most beautiful virtue, gratitude; and the grateful person acknowledges that there is usually a small party going on in the back of the mind. (p. 220)

Craddock sien humor as 'n natuurlike reaksie op genade, en hy sien grappe as afleidend en gevaarlik.

'n Groot hoeveelheid van die kritiek teen grappe in prediking kom uit die gebruik van grappe as inleiding tot preke. Buttrick (1987:95) verduidelik dat sprekers dikwels toesprake inlei met 'n grap om die gehoor te laat ontspan. Daardie idee het oorgespoel na prediking, maar werk baie selde. ${ }^{13}$ 'n Grap aan die begin van ' $n$ preek is gewoonlik geskei van die geheel van die preek. Long (2016:211) beklemtoon juis dat ' $n$ inleiding met die res van die preek verbind moet wees. Grappe het duidelik te make met 'n negatiewe vorm van inkulturasie ${ }^{14}$ (Wepener 2008:316). Duidelik spoel sommige negatiewe aspekte van die 'after-dinner speech' kultuur, soos Buttrick (1987:95) daarna verwys, oor na prediking wat nuwe verwagtinge soos vermaaklikheid skep by hoorders waaraan die prediker voel hy of sy moet voldoen.

\section{Sarkasme en persoonlike grappe}

Private grappe sluit mense uit en laat die ruimtes verbrokkel waar mense gemaklik voel om te lag (Troup 2009:58). Sarkasme, in 'n eenvoudige vorm, is 'n uitdrukking van minagting of vyandigheid teenoor ' $n$ persoon of 'n groep mense. Buttrick (1987) benadruk die negatiewe gebruik van sarkasme in prediking:

12.Miller (1994:105-106) gee verskeie redes waarom grappe gevaarlik is in prediking Die eerste gevaar van grappe vir Miller is die duidelike moontlikheid dat ' $n$ grap oud en uitgeput kan wees en ook afleidend kan wees. 'n Tweede gevaar volgens Miller is dat ' $n$ grap ernstige en belangrike waarhede in ' $n$ preek kan belemmer. Grappe kan ook tot gevolg hê dat die prediker se intellek bevraagteken kan word.

13.Grappe werk selde, maar daar is ook' $n$ teologiese teenstrydigheid met betrekking tot wat liturgie en prediking is, en wat 'n gewone toespraak is of wil bereik.

14.Wepener (2009:36) stel dat inkulturasie verwys na ' $n$ voortdurende proses van kritiese wedersydse interaksie tussen kultus en kultuur sodat daar 'n totaal nuwe entiteit tot stand kan kom
Laughter prompted by sarcasm is seldom helpful. Sarcasm is always a form of veiled hostility; it is essentially murderous. Thus, when people laugh at witty sarcasms, they will usually laugh out of shared hatreds. Such laughter in a sermon is rather clearly alien to the gospel. (p. 146)

Swets in Troup (2009:58) stel dat wanneer 'n gehoor agterkom dat 'n spreker nie vir hulle omgee nie, hou hulle op luister. Dit is duidelik dat liefde 'n groot rol speel wanneer dit by humor in prediking kom. Tisdale (2010) en Wogaman (1998) skryf oor die belangrikheid van liefde in profetiese prediking. Tisdale (2010:43) stel uitdruklik: 'We cannot fake love in the pulpit'. As die basis van God se Woord liefde is, hoe kan daardie boodskap oorgedra word as dit nie uitgedruk word in 'n konteks van liefde nie? Wogaman (1998:21) beklemtoon ook hierdie stelling: 'We cannot preach about love un-lovingly; it is a self-contradiction'.

\section{Oneffektiewe poging tot gebruik van humor}

Nog 'n moontlike gevaar is die oneffektiewe poging tot die gebruik van humor. Pogings tot humor wat nie snaaks is nie, kan ook 'n prediker in 'n baie ongemaklike posisie plaas, wat 'n ongewenste uitkoms is. Niemand verstaan humor deur daarvoor te lag nie; iemand lag omdat hy of sy dit verstaan. Dus, moet 'n prediker humor gebruik wat goed deurdink en voorberei is indien hy of sy oortuig is dat vir'n spesifieke doel gebruik kan word.

Konteks is uiteraard ook baie belangrik. Humor wat goed werk in 'n klassieke oggenddiens met ouer lidmate, gaan nie noodwendig dieselfde reaksie ontlok by ' $n$ aanddiens met tieners en jong werkendes nie. ${ }^{15}$ Die prediker moet dus die lewering van die humoristiese stuk so goed voorberei en bemeester soos wat hy of sy ander aspekte van 'n preek voorberei (Barnette 1992:189).

\section{Prediker as nar (negatief)}

Oor die laaste vier dekades is daar verskeie navorsingswerk gedoen oor die invloed van persoonlikheid op humor (Martin 2007; Martin en Lefcourt 1984; Svebak 1974). Een van hierdie gevolgtrekkings oor humorstyle is deur sielkundiges geïdentifiseer as kompulsiewe humoriste, die nar-persoonlikheid, of soos Wiersbe (2001:ad loc) daarna verwys: 'clerical jesters'. Kompulsiewe humoriste is: 'Those who seem unable to stop cracking jokes, making humorous observations, and behaving like clowns' (Ziv 1984:170).

Terwyl hierdie persone ' $n$ mate van pret en plesier kan lewer in 'n sosiale atmosfeer, kan hulle toehoorders vinnig moeg word vir hul onophoudelike grappige gedrag. Kompulsiewe humoriste sukkel dikwels met die hantering van die ernstiger aspekte van die lewe (Barnette 1992:258). Konstante impulsiewe humor kan 'n manier word om konfrontasie met ander te vermy. Die aanhoudende gebruik van humor as 'n poging tot sosiale aanvaarding val naderhand plat. Terwyl kompulsiewe humoriste gewild is oor hulle humorsin, geniet 15.Barnette (1992:189) se navorsing wys daarop dat die intelligensie van die gehoor ook in ag geneem moet word wanneer humor gebruik word. 
hulle in 'n gemeenskap nie hoë aansien in terme van leierskap, geloofwaardigheid en invloed nie (Barnette 1996:3).

\section{Relevante humor}

Halford Luccock (1944:169) het reeds in die 1940's die belangrikheid van relevante humor beklemtoon. Relevante humor verwys na die idee om humor in 'n erediens te gebruik wat relevant is tot die geheel van die boodskap en die erediens as geheel.

Luccock (1944:169) het destyds 'n trein as metafoor gebruik om relevante humor te verduidelik. Hy vergelyk humor in prediking met die vonke wat deur 'n trein veroorsaak word wanneer die wiele van die trein teen die spore skuur terwyl die trein na 'n bestemming beweeg. Hy beklemtoon dan: 'There is no stopping the train for the purpose of showing off some sparks'. Die vonke belemmer nie die beweging van die trein of vervang 'n klein vertoning van vuurwerke vir beweging vorentoe nie. Vonke is bykomend tot die beweging - 'n produk van die wrywing van die wiele op die spore.

Preekhumor wat toevallige en af-en-toe produkte van die wrywing tussen die verstand en idees vereis, kan van groot waarde wees vir prediking. Maar humor wat die gedagtegang vertraag of die trein dwing om op 'n sypaadjie te stop totdat die humoristiese vertoning verby is, is ' $n$ struikelblok vir die primêre doel van prediking.

\section{Gevolgtrekking}

As ' $n$ prediker preek vanuit ' $n$ verstaan van prediking waar die hoofdoel vermaaklikheid is, sou kritiek op onaanvaarbare humor heelwat anders gelyk het. Uit die aard van die saak sou baie van die onaanvaarbare humor wat hier bo vermeld is, aanvaarbaar wees. Long (2016:12) wys dat gemeentes dikwels tevrede is wanneer preke lewendig, boeiend en nie vervelig is nie, maar wyse predikers weet dat gemeentes ook ordentlike substansie nodig het - prediking wat meer bied as om net vir vermaaklikheid te sorg.

\section{Goeie kanselhumor}

Daar is 'n magdom verskillende positiewe soorte humor waartoe ' $n$ prediker toegang het in prediking. Sommige tipes is makliker om te gebruik en is veiliger as ander. Onderstaande is 'n paar van die 'veiliger' tipes humor wat tot die beskikking van die prediker is.

\section{Snaakse verhale of stories}

Heflin (1974:152) het reeds in die 1970's daarop gewys dat verhale die basis van komiese prediking vorm as hy stel dat verhale die 'strongest and most characteristic form of humor' is. Norrick (2009:397) stel ook: 'Our everyday talk thrives on all kinds of stories, especially humorous ones'. Hoe ook al gestel, verhale is die prototipe van alle menslike komedie. Dit vorm ook die basiese bestanddeel van komiese prediking
(Webb 1998:55). ${ }^{16}$ Humoristiese verhale het geweldige emosionele aantrekkingskrag en illustratiewe waarde, en kan gebruik word om punte te illustreer en hoorders se belangstelling te wek (Rushing 2006:45).

Barnette (1992:231) is van mening dat die moontlikheid bestaan dat die prediker humor as'n sosiale beheermeganisme kan gebruik, veral met betrekking tot verhale. Humoristiese verhale kan gedeelde tekortkominge van lidmate uitwys. Die humor in die verhaal onthul die algemene menslikheid en stel die mense in staat om vir hulself te lag. Deur vir hulself te lag, herposisioneer lidmate hul identiteit en sien hulself duideliker.

\section{Teenstrydighede}

Een van die beste wyses om humor in prediking te gebruik, is deur teenstrydighede. Morreall (2009:10) wys uit dat teenstrydighede tans die dominante humor in die filosofie en sielkunde is, en dit is heel moontlik ook waar van prediking. Dit is die beginsel om saam te voeg wat nie normaalweg saam gaan nie, om een ding te soek en iets anders te kry. In prediking kan teenstrydighede waardevol wees. Webb (1998) wys op verskeie tipes teenstrydighede in kommunikasie wat deur predikers gebruik kan word.

Een vorm van teenstrydigheid is wat tussen die verwagse en die onvoorsiene gevind word. Morreall (2009:15) wys daarop dat ons as mense in patrone of roetines leef. Ons weet wat om te verwag van ander, hoe mense optree en hoe verskynsels gebeur. Dit is wanneer daardie verwagtinge op 'n manier onderbreek word wat die komiese moontlikhede na vore tree.

'n Tweede teenstrydigheid is dié tussen 'n individu en 'n instelling; tussen 'n persoon en 'n reuse burokrasie; 'n geïsoleerde persoon en die stelsel (Webb 1998:82). Hierdie teenstrydigheid resoneer duidelik in 'n Suid-Afrikaanse konteks waar 'n mens dikwels baie lank in rye staan by munisipale kantore of vir ure moet aanhou in telefoongesprekke om 'n foutiewe telefoonlyn te rapporteer. Alhoewel gebeurtenisse soos hierdie nie altyd komies is nie, is dit goud werd vir predikers.

\section{Woordspeling}

Nog 'n soort humor beskikbaar vir die prediker, alhoewel dit spaarsaam gebruik moet word, is woordspeling. Woordspeling, of humor deur die manipulasie van woorde, vind plaas wanneer die luisteraar verwag dat'n woord op 'n voorspelbare wyse gebruik word, maar is verbaas wanneer die prediker dit op 'n heeltemal ander manier gebruik (Rushing 2006:46).

Woordspeling word dikwels uitgedruk in die vorm van 'puns', verkeerde uitspraak van woorde, 'n woord of frase

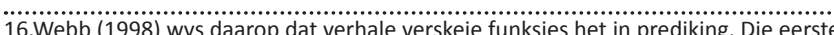
is dat verhale dikwels ' $n$ vergelykende rol in die preek speel (Webb 1998:58). Hulle kommunikeer soos ' $n$ gelykenis. ' $n$ Tweede rol wat verhale in die preek kan speel, is die skepping van ' $n$ gedeelde ervaring (Webb 1998:58). ' $n$ Derde rol, is ' $n$ gedragsrol. ' $n$ Verhaal kan met ander woorde ' $n$ 'gaan en doen net so' effek hê. 
met twee moontlike interpretasies ('double entendres') en 'spoonerisms', mondelinge foute waarin 'n spreker die oorspronklike klanke of letters van twee of meer woorde per ongeluk omruil.

Woordspeling word meer dikwels opsetlik gebruik waar 'n woord met 'n 'verwagte' betekenis gestel word in 'n omgewing wat die woord se betekenis verskuif na iets wat nie verwag word nie. Dit is 'n voor die hand liggend en goedkoop vorm van humor; so goedkoop dat ons dikwels kreun en sug in plaas daarvan om te lag.

\section{Die prediker}

Uiteraard speel die prediker self 'n groot rol in 'the event of preaching', waar Long (2016:15) die prediker uitlig as een van die belangrikste deelnemers in die preekgebeurtenis.

\section{Outentieke humor}

Een van die mees sentrale aspekte van humoristiese prediking is die beklemtoning van die egtheid van die prediker. Verskeie homilete en kommunikasiekundiges (Beukema 2005:ad loc; Buttrick 1987:146; Finestad 2010:46; Miller 1994:105; Troup 2009:60) benadruk die gedagte dat 'n prediker net hom of haarself moet wees as dit by die gebruik van humor op die kansel kom. Volgens Miller (1994:105): 'Nothing enhances authenticity (and sparkle) like the art of being ourselves'. Dit is die rede waarom professionele komediante so suksesvol is. Hulle het geleer om hul natuurlike humoristiese neigings te betrek en 'n styl te gebruik wat by hul persoonlikhede pas. ${ }^{17}$

\section{Talent van humor}

Nelson (1998:5) stel die vraag: 'What if humor is not one of your gifts?' Behoort predikers wat nie 'n natuurlike 'kanselvriendelike' humorsin het nie (soos Martin [2007:216] daarna verwys: 'the ability of humor') humor te gebruik in prediking? Nelson (1998:5) stel dat dit dan beter is om nie te probeer om snaaks te wees nie. Dit is ook Buttrick (1987:146) se mening. Long (2016:14) is eerder van mening dat goeie prediking uit harde werk en toewyding spruit. Predikers vir wie humor nie so natuurlik kom soos by ander nie, hoef nie noodwendig humor te vermy uit vrees vir mislukking nie, maar kan eerder riglyne volg oor watter humor om te vermy en watter humor om te gebruik.

\section{Selfopenbaring en selfverminderende humor}

Selfopenbaring en selfverminderende humor kan maniere wees om in jou eie stem te preek en humor sodoende op 'n outentieke manier te gebruik in prediking (Finestad 2010:47). Selfopenbaring is die verbale en nie-verbale openbaring van die spreker se gevoelens, waardes en/of persoonlike ervarings vanaf die kansel (Arthurs \& Gurevich 2000:215). Selfverminderende humor verwys weer na selfopenbaring wat gestalte vind in die gekskeer met die prediker deur die

17. Beukema (2005: ad loc) meen dat'n prediker humor moet gebruik wat by sy of haar persoonlikheid en styl pas: 'If you don't do it within a conversation, you are wise to avoid it in public'. prediker. Dit verwys na predikers wat hul eie foute en swakpunte op 'n humoristiese wyse oordra aan 'n gemeente.

Die gebruik van selfverminderende humor kan die stereotipe van predikers as arrogant omvergooi en die indruk van nederigheid deurgee, en ook die prediker help om te identifiseer met die menslikheid, probleme en swakpunte van sy of haar lidmate (Troup 2009:54).

Barnette (1992:148-149) wys ook na 'n ander kant van selfverminderende humor. Selfverminderende humor blyk 'n lewensvatbare en effektiewe opsie vir predikers te wees wat 'n hoë status in die gemeenskap bereik het. Barnette se navorsing dui daarop dat hierdie humor slegs effektief is wanneer dit deur predikers gebruik word wat reeds as geloofwaardig beskou word. In ideale omstandighede beskik 'n gevestigde prediker oor 'n groot mate van geloofwaardigheid en kan hierdie humor as ' $n$ instrument van identifikasie met sy of haar gemeente gebruik word. Maar 'n prediker wat nuut in die gemeente is of net per geleentheid by 'n gemeente preek, behoort eerder nie sulke humor te gebruik nie - ten minste nie in die begin nie. Predikers wat te vroeg met hulself spot, skep dikwels 'n gevoel van onsekerheid en 'n gebrek aan selfvertroue by 'n gemeente. Waar dit die geval is, het dit 'n negatiewe uitwerking op die gemeente (Barnette 1992:149).

\section{Gemeentelike perspektiewe op humoristiese prediking Verbinding met hoorders}

Om 'n suksesvolle verhouding met hoorders te bou, is ' $n$ noodsaaklike funksie van enige kommunikeerder (Cloud 2006:69-71). Een waardevolle ondersteunende funksie van humor, volgens Meyer (2000:318), is om kommunikeerders te helpommethullegehoor teidentifiseer, diegeloofwaardigheid van die spreker te verhoog, en samehorigheid by 'n groep te bevorder. Die waardering van' $n$ sin vir humor is ' $n$ belangrike deel van die groei en verdieping van verhoudings tussen mense, soos 'n gemeente, aangesien onderlinge onsekerheid verminder word en samehorigheid geskep word (Graham 1995).

\section{Die houding van die hoorders teenoor die prediker}

Barnette (1992:191) wys op dié manier hoe die sielkundige ingesteldheidsteorie van toepassing kan wees op die houding van die hoorders teenoor die prediker. Hoe meer die hoorders van 'n prediker hou, hoe groter is hul reaksie op die prediker se humor. Trouens, hoe minder hulle van die prediker hou, hoe minder sal hulle die prediker se humor geniet. Daarbenewens is dit belangrik dat die prediker ' $n$ gesonde etos het wat afhanklik is van goeie interpersoonlike verhoudings met sy of haar gemeente. As die prediker swak verhoudings het of in die middel van ' $n$ konflik met gemeentelede is, is die kans groot dat sy of haar pogings tot humor sal misluk. 
Humor kan ook sosiale interaksie tussen prediker en gemeente fasiliteer. Die humor wat tussen prediker en hoorders gedeel word, lewer 'n gedeelde ervaring van dialoog tussen die twee partye. Voorts kan humor die 'toets' positief beïnvloed waardeur elke prediker in die hande van 'n gemeente onderwerp word. Deur effektiewe humor te gebruik, kan die prediker meer geredelik aanvaar word en makliker deel word van 'n bepaalde kerklike konteks (Barnette 1992:225).

\section{Gevolgtrekking}

Dit is duidelik dat daar 'n groot leemte in die homiletiese werk is wat humor in prediking betref. Handleidings oor Christelike prediking het min en somtyds niks te sê oor die gebruik van humor in prediking nie. 'n Moontlike rede hiervoor is dat humor nie 'n baie voor die hand liggende onderwerp is soos wat veronderstel word nie. Die oorgrote meerderheid van die paar homilete wat wel oor die onderwerp skryf, sien humor egter as 'n toepaslike instrument vir gebruik in prediking, alhoewel daar verskeie punte van kritiek teen humor en die gebruik daarvan in prediking is.

Wat humor in die Bybel betref, wil dit voorkom of die meeste gevalle van humor in die Bybel in natuurlike kontekste afspeel en ongeforseerd voorkom, wat vir preekdoeleindes belangrik is. Daar is tog duidelike waarskuwings aan die prediker oor verskeie soorte humor wat eerder vermy behoort te word. Bygesê, 'n prediker se humor het'n aansienlike impak op sy of haar verhoudings met die gemeente. Gemeentes se siening van 'n prediker kan ook grotendeels gevorm word deur sy of haar tipe humorgebruik. Daar is egter ' $n$ groot hoeveelheid 'positiewe' humorsoorte om van te kies vir gebruik in die erediens.

Daar bestaan dus potensiaal ten opsigte van die gebruik van humor in die prediking, alhoewel dit, in die lig van die navorsing wat vir hierdie artikel gedoen is, met groot omsigtigheid behoort te geskied.

\section{Erkenning \\ Mededingende belange}

Die outeurs verklaar dat hulle geen finansiële of persoonlike verbintenis het met enige party wat hulle nadelig kon beïnvloed het in die skryf van hierdie artikel nie.

\section{Outeursbydrae}

Navorsing oorspronklik gedoen vir die MTh verhandeling deur G.B. wat verwerk is in ' $n$ artikel. C.W. het gedien as studieleier vir die MTh-verhandeling.

\section{Literatuurverwysings}

Arminen, I. en Halonen, M., 2007, 'Laughing at patiens: The rules of laughter in confrontations in addiction therapy', The Qualitative Report 12(3), 484-513.

Arthurs, J.D. en Gurevich, A., 2000, 'Theological and rhetorical perspectives on selfdisclosure in preaching', Bibliotheca Sacra 157(1), 215-226.
Barnette, J.R., 1992, 'Humor in preaching: The contributions of psychological and pociological research', PhD Proefskrif, Die Southern Baptist Teologiese Seminarium.

Barnette, J.R., 1996, 'A time to laugh: Principles of good pulpit humor', viewed 19 July 2017, from https://www.preaching.com/articles/a-time-to-laugh-principles-ofgood-pulpit-humor/

Beukema, J.H., 2005, Why serious preachers use humor (Part 1), viewed 19 July 2017, from http://www.preachingtoday.com/skills/themes/humor/200403.30.html

Buttrick, D., 1987, Homiletic: Moves and structures, Fortress Press, MN.

Campbell, C.L. en Cilliers, J.H., 2012, Preaching fools: The gospel as a rhetoric of folly, Baylor University Press, Waco.

Capps, D.E., 2016, Humor us: An appeal for the Gospel of Relaxation, Cascade Books, Eugene OR.

Cilliers, J.H., 2004, Die lewende stem van die evangelie. Nuut gedink oor die basiese beginsels van prediking, Sun Press, Stellenbosch.

Cilliers, J.H., 2008, 'The clown before the powers. A South African response to Charles Campbell's comic vision on preaching'. Journal of the Academy of Homiletics 33(2), 1-10. https://doi.org/10.15695/hmltc.v33i2.3290

Cilliers, J.H., 2009, 'Clowning on the pulpit? Contours of a comic vision on preaching. Scriptura', International Journal of Bible, Religion and Theology in Southern Africa 101, 189-197.

Cilliers, J.H., 2010, 'Clowning for change. Comments on Charles Campbell's comic vision on preaching. Preaching: Does it make a difference?' Studia Homiletica 7, 33-36. M. Lindhart \& H. Thomsen (eds.), Aros Vorlag, Frederiksberg.

Cloud, H., 2006, Integrity: The courage to meet the demands of reality, Harper Collins, New York.

Craddock, F.B., 2010, Preaching, 2nd edn., Abingdon Press, Nashville, TN.

Drakeford, J., 1986, Humor in preaching, Zondervan, Grand Rapids, MI.

Finestad, C.A., 2010, 'The use of humor in preaching and its relationship with ethos, relational solidarity, and affective learning', PhD Proefskrif. Asbury Teologiese Seminarium.

Ford, T.E., Boxer, C.F., Armstrong, J. \& Edel, J.R., 2008, 'More than "Just a Joke": The prejudice-releasing function of sexist humor', Personality and Social Psychology Bulletin 34(2), 159-170. https://doi.org/10.1177/0146167207310022

Goldman, C., 2009, Healing words for the body, mind, and spirit: 101 words to inspire and affirm, Morehouse Publishing, New York.

Gouws, R.H., Luther, J. \& Pheiffer, F., 2015, HAT: Handwoordeboek van die Afrikaanse taal, Pearson, Kaapstad.

Graham, E.E., 1995, 'The involvement of sense of humor in the development of social relationships', Communication Reports. 8(1), 158-170. https://doi.org/10.1080/ 08934219509367622

Greenstein, E.L., 1992, 'Humour and wit in the Old Testament', in D.N. Freedman (ed.), The Anchor Bible Dictionary, vol. 3 (H-J), pp. 330-333, Doubleday, New York.

Haig, R.A., 1988, The anatomy of humor: Biopsychosocial and therapeutic perspectives, Charles C. Thomas Publishers, Springfield.

Hart, A.D., 2007, Thrilled to death: How the endless pursuit of pleasure is leaving us numb, Thomas Nelson, Nashville, TN.

Heflin, J., 1974, 'An evaluation of the use of humor in the sermon', PhD Proefskrif, Southwestern Baptist Teologiese Seminarium.

Herion, G.A., 1992, 'Humour and wit', in D.N. Freedman (ed.), The Anchor Bible Dictionary, vol. 3, Doubleday, New York.

Hijri, F., 2009, 'Somebody going to get hurt real bad': The race-based comedy of Russell Peters', Canadian Journal of Communication 34(4), 567-586.

Hyers, C., 1987, The comic vision and the Christian faith: A celebration of life and laughter, Wipf \& Stock Pub, Eugene.

Kuschel, K.J., 1994, Laughter: A theological essay, SCM Press, London.

Lebowitz, K.R., Suh, S., Diaz, P.T. \& Emery, C.F., 2011, 'Effects of humor and laughter on psychological functioning, quality of life, health status, and pulmonary functioning among patients with chronic obstructive pulmonary disease: A preliminary investigation', Heart \& Lung 40(4), 310-319. https://doi.org/10.1016/j.hrtlng. 2010.07.010

Lefcourt, H.M. en Martin, R.A., 2012, Humor and life stress: Antidote to adversity, Springer Science \& Business Media, New York.

Long, T., 1989, Preaching and the literary vorms of the Bible, Fortress Press, Philadelphia.

Long, T., 2016, The witness of preaching, 3rd edn., Westminster/John Knox Press, Kentucky.

Long, D.L. en Graesser, A.C., 1988, 'Wit and humor in discourse processing', Discourse Process 11(1), 35-60. https://doi.org/10.1080/01638538809544690

Luccock, H.E., 1944, In the minister's workshop Abingdon-Cokesbury, New York.

Lynch, O.H., 2011, 'Humorous communication: Finding a place for humor in communication research,' Communication Theory. 12(1), 423-429.

Martin, J., 2011, Between heaven and mirth: Why joy, humour and laughter are at the heart of the spiritual life, Harper Collins, New York.

Martin, R.A., 2004, 'Sense of humor and physical health: theoretical issues, recent findings, and future directions', International Journal of Humor and Research 17(1 en 2), 1-19.

Martin, R.A., 2007, The psychology of humor: An integrative approach, Elsevier Academic Press, San Diego, CA.

Martin, R.A. en Lefcourt, H.M., 1984, 'Situational humor response questionnaire: Quantitative measure of sense of humor', Journal of Personality \& Social Psychology 47(1), 145-155. https://doi.org/10.1037/0022-3514.47.1.145 
Meyer, J.C., 2000, 'Humor as a double-edged sword: Four functions of humor in communication', Communication Theory 10(3), 310-331. https://doi. org/10.1111/j.1468-2885.2000.tb00194.x

Miller, C., 1994, The empowered communicator: 7 keys to unlocking an audience, Broadman, Nashville, TN.

Miller, M. en Fry, W.F., 2009, 'The effect of mirthful laughter on the human cardiovascular system', Medical Hypotheses 73(5), 636-639. https://doi. org/10.1016/j.mehy.2009.02.044

Morreall, J., 2009, Comic relief: A comprehensive philosophy of humor, John Wiley \& Sons, Ltd, Hoboken.

Nelson, W.W., 1998, 'Taking pulpit humor seriously', Covenant Quarterly 56(2), 3-14.

Niebuhr, R., 1946, Discerning the signs of the times -Sermons for today and tomorrow, C. Scribner's Sons, New York.

Norrick, N.R., 2009, 'A theory of humor in interaction', Journal of Literary Theory 3(2), 261-284.

Palmer, E.F., 2001, The humor of Jesus, Regent College Publishing, Vancouver.

Patella, M., 2015, 'And God created laughter, the eighth day', A Jounral of Bible and Theology 69(2), 156-168.

Philips, M., 1984, 'Racist acts and racist humor', Canadian Journal of Philosophy 14(1) 76.

Rogness, M., 2012, 'Humor in the Bible', Word \& World 32(2), 117-123.

Rushing, B.M., 2006, 'Toward a methodology which equips pastors to use humor intentionally in preaching', PhD Proefskrif, New Orleans Baptist Teologiese Seminarium.

Simpson, J.A. en Weiner, E.S.C., 1989, The Oxford English Dictionary, 2nd edn., vol. 7, Clarendon Press, Oxford.

Spitzer, P., 2006, 'Hospital clowns - Modern-day court jesters at work', Lancet Medicine and Creativity 368(1), 534-535.

Svebak, S., 1974, 'Revised questionnaire on the sense of humor', Scandinavian Journal of Psychology 15(1), 328-331. https://doi.org/10.1111/j.1467-9450.1974.tb00597.x
Theron, P.F., 1996, 'Liberating humour. Calvinism and the comic vision', in A. van Egmond \& D. van Keulen (eds.), Freedom! Studies in Reformed Theology, pp. 208-232, Callenbach uitgeverij, Belgie.

Tisdale, L.T., 2010, Prophetic preaching: A pastoral approach, Westminster John Knox Press, Louisville, KY.

Tisdale, L.T. en Troeger, T.H., 2013, A sermon workbook: Exercises in the art and craft of preaching, Abingdon Press, Nashville, TN.

Troup, A., 2009, 'Humor in preaching: Its effects and guidelines for its beneficial use', PhD Proefskrif, Concordia Seminarium.

Van der Meulen, H., 2008, Als een leerling leren preken, Boekencentrum, Utrecht.

Van Heerden, W., 2001, 'Why the humour in the Bible plays hide and seek with us', Social Identities 7(1), 75-96. https://doi.org/10.1080/13504630120043530

Webb, J., 1998, Comedy and preaching, Chalice Press, Atlanta, GA.

Wepener, C.J., 2008, 'Liturgy on the edge of tradition', Praktiese Teologie in Suid Afrika 23(2), 313-335.

Wepener, C.J., 2009, From fast to feast: A ritual-liturgical exploration of reconciliation in South African cultural contexts, Peeters Publishers, Leuven.

Whedbee, W., 1998, The Bible and the comic vision, Cambridge University Press, Cambridge.

Wiersbe, W., 2001, H is for Humor, viewed 11 August 2017, from http:// www.2prophetu.com/templates/!print/details.asp?id=35585\&PG=resources\&C ID $=18818$

Wogaman, J.P., 1998, Speaking the truth in love: Prophetic preching to a broken world, Westminster John Knox Press, Louisville, KY.

Wyer, R.S. en Collins, J.E., 1992, 'A theory of humor elicitation', Psychological Review 99(4), 663-688. https://doi.org/10.1037/0033-295X.99.4.663

Young, J.W., 2009, 'The relationship between sense of humor, leader-follower distance, and tenure in pastoral ministry', PhD Proefskrif, Southern Baptist Teologiese Seminarium.

Ziv, A., 1984, Personality and sense of humor, Springer Publishing Company, New York. 